https://helda.helsinki.fi

Developing microbial spoilage population in vacuum-packaged charcoal-broiled European river lamprey (Lampetra fluviatilis)

\title{
Merivirta, Lauri
}

Elsevier

2005

International journal of food microbiology. 2005. 101(2): 145-152.

http://hdl.handle.net/1975/519

http://dx.doi.org/10.1016/j.ijfoodmicro.2004.10.046

Downloaded from Helda, University of Helsinki institutional repository.

This is an electronic reprint of the original article.

This reprint may differ from the original in pagination and typographic detail.

Please cite the original version. 
Developing Microbial Spoilage Population in Vacuum-packaged

1Department of Food and Environmental Hygiene,

17 Faculty of Veterinary Medicine,

18 P.O. Box 57; FIN-00014 University of Helsinki, Finland ;

2Porilab, Tiedepuisto 4, FIN-28600 Pori, Finland

\footnotetext{
* Corresponding author, Tel: +358-2-6213324; Fax: +358-2-6213333;

Email: lauri.merivirta@fimnet.fi
} 

6 7 8

\section{ABSTRACT}

Microbiological and sensory changes in vacuum-packaged charcoal-broiled river lampreys from three lamprey processing plants were monitored as a function of time at $8^{\circ} \mathrm{C}$. The lampreys were examined every 7 days up to 8 weeks for aerobic plate count (APC) and lactic acid bacteria (LAB). The highest mean APC and LAB were $6.01 \mathrm{log}$ CFU/g and 4.86 $\log$ CFU/g, respectively. Only 6 out of 15 lots reached an APC value of 7.0 log CFU/g during storage. The sensory scores remained at the baseline levels after 8 weeks' storage. Twenty-seven isolates were randomly picked from MRS agar and identified to species level using a 16S and 23S rDNA HindIII RFLP (ribotyping) database and sequencing of the 16S rRNA gene if no database match was obtained. Twelve of the 27 isolates were identified as Lactobacillus curvatus subsp. curvatus, and two Leuconostoc mesenteroides and one Weissella halotolerans strain were also detected. Twelve isolates were not identified by the LAB database. However, they possessed very high (99.9\%) 16S gene sequence similarity with either Staphylococcus warneri or Staphylococcus pasteuri type strains. The LAB detected, with the exception of $W$. halotolerans, have commonly been associated with spoilage of fishery products, but in these vacuum-packaged lampreys they were not the dominant organisms within the developing spoilage population.

Key words: River lamprey; Sensory property; Spoilage; Vacuum-packaging; Aerobic plate count; Lactic acid bacteria; Staphylococcus; Ribotyping; 16S ribosomal gene sequencing (1) 


\section{Introduction}

50

European river lamprey (Lampetra fluviatilis) is a rare food item in the Baltic Sea region

where the charcoal-broiling on burning alder is the traditional way of processing lampreys.

The annual catch in Finnish coastal rivers of 1500000 - 2000000 lampreys is used for human consumption only (Ikonen et al., 1982; Tuunainen et al., 1983). Lampreys feed on fatty fish such as Baltic herring and sprat. Therefore the fat deposits may account up to $47 \%$ of the dry weight. The lampreys stop feeding in the beginning of the spawning migration and fishing season in August (Ikonen et al., 1982) and their intestinal flora is reduced thereafter. The fishing season continues to December. The amount of lampreys brought to the market in Finland was $25000 \mathrm{~kg}$ in 1997 (Finnish Game and Fisheries Research Institute, 1999). Lampreys are often sold in open-air booths, where temperature changes are possible. They are normally eaten without any further heating. Because the product is perishable and normally brought to the market without chilling, it was important to investigate the microbiological and sensory changes in vacuum-packaged, chilled product in order to develop the hygienic quality of the product.

65

Merivirta et al. (2003) studied the development of microbial levels in charcoal-broiled river lampreys stored at $22^{\circ} \mathrm{C}$ and $3^{\circ} \mathrm{C}$. They found that on the production day the mean aerobic plate count (APC) in broiled lampreys was between 1.67 and 2.29 log CFU/g depending on the manufacturer. At $22^{\circ} \mathrm{C}$, the mean APCs of samples increased markedly within 4 days, and after 6 days they were between 5.04 and 6.23 log CFU/g. Chilling and storing at $3^{\circ} \mathrm{C}$ improved the shelf-life of the product. The mean APC did not exceed 2.82 $\log$ CFU/g during 24 days of storage. However, neither the effect of vacuum-packaging nor sensory changes were studied. 
75 Lactic acid bacteria (LAB) often form the main bacterial group in vacuum-packaged

76

slightly preserved fishery products stored at chilled temperatures. This has been observed in many different types of fish products, including cold-smoked herring (Magnússon and Traustadóttir, 1982) and vacuum-packaged, cold-smoked salmon and rainbow trout (Shimasaki et al., 1994; Civera et al., 1995; Truelstrup Hansen, 1995; Leroi et al., 1998; Lyhs et al., 1998). The lamprey product differs from those being actually not smoked but charcoal broiled. To the authors knowledge no data exists on the microbiological development in charred vacuum-packaged lamprey. We therefore set out to compare changes in products of three manufacturers (A, B and C) with respect to developing LAB and to identify the dominant species in these products. Further aims were to determine the shelf-life of vacuum-packaged charcoal-broiled river lampreys and to observe sensory changes in products during storage.

\section{Materials and methods}

\subsection{Processing of lampreys}

The three plants used a traditional charcoal broiling procedure originating from centuries past. The methods used to produce charred lamprey are transferred from father to son. Lampreys are rubbed, in the round, with salt in a motorized, stainless steel apparatus resembling a concrete mixer. The process is carried out at room temperature.

Manufacturer A added 1,3 kg (one litre) of crystalline salt ( $\mathrm{NaCl}$ ) for every $40 \mathrm{~kg}$ of lampreys, and manufacturer B used about $1 \mathrm{~kg}$ of salt for $50 \mathrm{~kg}$ of product, although this 
depended on the consistency and the origin of the lampreys. The amount of salt used in plant $\mathrm{C}$ was $1 \mathrm{~kg}$ for every $50 \mathrm{~kg}$ of product. The mixing time in the running apparatus varied from $1 \mathrm{~h}$ to $1 \mathrm{~h} 30$ min depending on the size, colour and origin of the lampreys. After salting, the lampreys were rinsed under running water for 5 min. The water used was tap water controlled by municipal authorities. After a waiting period of $12 \mathrm{~h}$, the lampreys were broiled in ovens over charcoal made from alder at the temperature of $300^{\circ} \mathrm{C}$ in average. The broiling time varied depending on the person in charge, with total time ranging from 20 to $30 \mathrm{~min}$. The chilling occurred at room temperature, and the product was delivered to the market with no further processing.

\subsection{Sampling}

A total of 450 lampreys were collected from five different production lots of each of the three plants. Each of these 15 samples was divided into eight subsamples, which were then vacuum-packaged using a VAC STAR 6500 ST packaging machine (Vac Star, Kerzens, Switzerland) in polyamide-polyethylene film (Suomen Union Verpackungs, Östersundom, Finland) with an oxygen permeability of $25 \mathrm{ml} \mathrm{O}_{2} / \mathrm{m}^{2} / 24 \mathrm{~h} / \mathrm{atm}\left(23^{\circ} \mathrm{C}, 75 \% \mathrm{RH}\right)$ and a water vapour permeability of $2.5 \mathrm{~g} / \mathrm{m}^{2} / 24 \mathrm{~h}\left(23^{\circ} \mathrm{C}, 85 \mathrm{RH}\right)$. This resulted in 120 packages, 40 from each plant, which underwent sensory and microbiological analyses associated with different storage time points at $8^{\circ} \mathrm{C}$.

Every week, after 1-8 weeks’ storage, one package from each plant was opened and a representative 10-g sample of lamprey was placed in a sterile stomacher bag (Seward Ltd., London, UK) with $90 \mathrm{ml}$ of saline-peptone solution ( $0.85 \% \mathrm{NaCl}, 0.1 \%$ peptone) (Maximal Recovery Diluent, Lab M Ltd., Bury, England) and homogenized with a 
stomacher (Lab-Blender 400, London, UK). The homogenized sample was serially diluted using saline-peptone solution (Lab M Ltd.). Each dilution was plated onto the appropriate media using a poured or spread plate technique depending on the method.

\subsection{Sensory evaluation, salt content and water activity}

Sensory evaluation was performed once a week to determine when the samples were spoiled. The sensory evaluation panel consisted of three trained judges who were familiar with off-flavour problems typical of lampreys. The samples were evaluated for aroma and taste using the method described by Amerine et al. (1965). All samples were coded by number and were presented to the panel in randomized order. The scale for taste was $0-10$, and arithmetic means were calculated from individual scores. The salt (chloride) concentration, expressed as $\% \mathrm{NaCl}$, was determined by potentiometric titration. In addition we made a separate experiment to determine the $\mathrm{a}_{\mathrm{w}}$ as a general indication of product composition.

\subsection{Enumeration of $A P C$ and $L A B$ and selection of $L A B$ strains for species identification}

Plate count agar (Oxoid Ltd., Hampshire, UK) was used for the enumeration of APC according to the ISO method (1991). LAB were enumerated by plating of the samples on MRS Agar (Oxoid Ltd., Basingstoke, Hampshire, England). The medium was inoculated using the spread plate technique, and the plates were incubated under anaerobic $\mathrm{CO}_{2}$ atmosphere (Anaerogen, Oxoid Ltd.) at $20^{\circ} \mathrm{C}$ for 5 days. Duplicate plates were incubated under aerobic conditions. From each sample, randomly picked colonies were pure-cultured using MRS broth and MRS agar (Oxoid Ltd.). Altogether 27 colonies were selected from 
149 the MRS plates and subjected to species-level identification. The colonies were selected

150 from the plates with the two highest dilutions showing growth.

151

152 For DNA extraction, MRS broth was inoculated and the tubes were grown at $25^{\circ} \mathrm{C}$ for $1-2$

153 days depending on the growth rate. After incubation, cells harvested from $1.5 \mathrm{ml}$ of MRS

154 broth were used for DNA extraction. If needed, the isolates were stored in MRS broth at $155-70^{\circ} \mathrm{C}$.

156

2.5. $16 S$ and 23S rDNA HindIII RFLP, Ribotyping

158

159 DNA was isolated using a modified (Björkroth and Korkeala, 1996a) guanidium

160 thiocyanate method of Pitcher et al. (1989). In this modification, the cell lysis solution

161 contains mutanolysin (250 U/ml, Sigma, St. Louis, MO, USA) in addition to lysozyme (25

$162 \mathrm{mg} / \mathrm{ml}$, Sigma). Restriction endonuclease treatment of $8 \mu \mathrm{g}$ of DNA was done using

163 HindIII restriction enzyme (New England Biolabs, Beverly, MA, USA) as specified by the 164 manufacturer. HindIII was chosen because it has been found to provide species-specific 165 patterns for various spoilage LAB (Björkroth and Korkeala, 1996b, 1997; Björkroth et al., 166 1998, 2000). Restriction endonuclease analysis (REA) was performed as described earlier

167 (Björkroth and Korkeala, 1996a). Genomic blots were made using a vacuum device

168 (Vacugene, Pharmacia, Uppsala, Sweden), and the rDNA probe for ribotyping was labelled

169 by reverse transcription (AMV-RT, Promega, Madison, WI, USA) using a Dig DNA

170 Labelling Kit (Roche Molecular Biochemicals, Mannheim, Germany) as previously

171 described by Blumberg et al. (1991). Membranes were hybridized overnight at $58^{\circ} \mathrm{C}$, and

172 detection of the digoxigenin label was performed as recommended by Roche Molecular

173 Biochemicals. 
175 2.6. Numerical analysis of HindIII ribopatterns

176

177 The membranes were scanned with a Hewlett-Packard ScanJet 4c/T tabletop scanner

178 (Boise, ID, USA). Numerical analysis of the ribopatterns was performed using the

179 Bionumerics 3.0 software package (Applied Maths, Sint-Martens-Latem, Belgium). Based

180 on internal controls, $1.5 \%$ position tolerance and $0.5 \%$ optimization was allowed for

181 bands/patterns. Similarity between all pairs was expressed by Dice coefficient correlations,

182 and the unweighted pair-group method with arithmetic averages (UPGMA) was used for

183 construction of the dendrogram. The ribopatterns were compared with the corresponding

184 patterns in the LAB database at the Department of Food and Environmental Hygiene,

185 University of Helsinki, Finland. This database includes patterns of all relevant spoilage

186 LAB in the genera of Carnobacterium, Lactobacillus, Leuconostoc, Enterococcus and

187 Weissella (Björkroth and Korkeala, 1996b, 1997; Björkroth et al., 1998, 2000).

188 Identification of the isolates was done based on locations of the type strains in the clusters.

189

190 2.7. Sequencing of $16 S$ rRNA gene

191

192 When ribotyping database analysis did not result in clear clusters, representative strains

193 from these clusters were subjected to 16S rRNA gene sequence analysis. The nearly

194 complete 16S rRNA gene was amplified by PCR with universal primer pair F8-27 (5'-

195 AGAGTTTGATCCTGGCTGAG-3’) and R1541-1522 (5’-

196 AAGGAGGTGATCCAGCCGCA-3'). Sequencing of the purified (QIAquick PCR

197 Purification Kit, Qiagen) PCR product was performed by Sanger's dideoxynucleotide

198 chain termination method using two long (primers F19-38 [5’- 
CTGGCTCAGGAYGAACGCTG-3’] and R1541-1522) and two shorter (primers F926 [5’-AACTCAAAGGAATTGACGG-3'] and R519 [5'-GTATTACCGCGGCTGCTG-3’]) reactions. Samples were run in a Global IR2 sequencing device with e-Seq 1.1 software (LiCor, NE, USA) according to the manufacturer's instructions. The similarity between these sequences and sequences in GenBank was determined using BLASTN 2.2.6 software (Altschul et al., 1997).

\subsection{Statistical analysis}

Student's t-test was used to calculate differences between plants in APC, LAB and sensory scores. When growth was under $3.0 \log$ CFU/g, the number used in statistical calculations was $2.70 \log \mathrm{CFU} / \mathrm{g}$.

\section{Results}

APC results are presented in Table 1. After one week of storage, APC was under 3.0 log CFU/g in all samples. After 2-8 weeks' storage, the mean APC increased in samples from plants A and C to 6.01 and $4.87 \log$ CFU/g, respectively, but remained under 3.0 log CFU/g in samples from plant B. Five samples from plant A and one sample from plant C exceeded an APC value of 7.0 log CFU/g after 6 weeks. In all samples from plant B, the APC was under $7.0 \log$ CFU/g. By week 8, APC in samples from the plant A was significantly higher than in samples from both plant $B(p<0.01)$ and plant $C(p<0.05)$.

The mean and range of LAB levels and the mean taste scores are presented in Table 2. After 8 weeks’ storage, the lampreys still received good sensory scores from the panel. The 
scores decreased slightly only in samples from plant C. No association was observed between taste scores and aerobic plate or LAB counts. The salt concentration obtained from vacuum-packaged samples was 2.5\% (1.5-3.4\%). The $\mathrm{a}_{\mathrm{w}}$ values tested varied between 0.93 and 0.98 .

After 2 weeks' storage, LAB counts of all samples incubated in anaerobic conditions were under 3.0 log CFU/g (Table 2), and no significant difference ( $>0.05$ ) was present between plants in any week. The level of bacteria grown on MRS under aerobic conditions was higher in samples from plant A than from plants B and C $(\mathrm{p}<0.05)$ after 7 weeks' storage. Overall, the counts of bacteria grown under aerobic conditions were higher than those grown under anaerobic conditions. After 3 weeks' storage, the proportion of LAB compared with APC from samples of plant A was $53 \%$, but this diminished after 6 and 8 weeks to $25 \%$ and $7 \%$, respectively. The mean APC was higher after 4-8 weeks' storage than the mean LAB levels; thus microbes in addition to LAB were present in the spoilage population.

Based on the isolates obtained from samples of plants A and C, we found five different ribotypes (Fig. 1). Ribotypes I (1 isolate) and IV-V (2 and 12 isolates, respectively) were isolated from samples originating from only plant A. Twelve isolates (ribotype V) from plant A possessed identical patterns to Lactobacillus curvatus subsp. curvatus (type strain DSM 20019) and two (ribotype IV) to Leuconostoc mesenteroides (type strains DSM 20484, DSM 20343). One isolate (ribotype I) from plant A showed a similar ribotype to that of Weissella halotolerans (type strain ATCC 35410). 
Eleven isolates (two strains) were not identified to species level by the RFLP LAB

249 database. When their 16S ribosomal encoding gene sequence similarities were compared

250 with the sequences in GenBank, both strains showed the highest similarities to

251 Staphylococcus strains. The following sequences were deposited in the GenBank

252 (http://www.ncbi.nlm.nih.gov): lamprey strains 24/1 (ribotype II) and 34/1 (ribotype III),

253 with accession numbers AY578091 and AY578092, respectively.

255 Nine isolates (ribotype III) from plant C showed 99.9\% similarity to Staphylococcus warneri type strain ATCC 27836 (GenBank accession number L37603). Two isolates from plant A and one from plant C possessed ribotype II and showed 99.9\% sequence similarity to Staphylococcus pasteuri type strain ATCC 51129 (GenBank accession number

259 AB009944).

\section{Discussion}

Our results indicate that microbial growth in lampreys is relatively slow. After 3 weeks' storage, the mean APC was 3.48 log CFU/g or less in the products of two plants and under the detection limit in the product of third plant. After 8 weeks, the highest mean APC reached was $6.01 \log$ CFU/g. Magnússon and Traustadóttir (1982) reported an APC in vacuum-packaged smoked herring fillets of 6.0 log CFU/g in less than 3 weeks' and >7.5

$268 \log$ CFU/g after 6 weeks’ storage. Thus, the lamprey product appears to remain edible for 269 at least 5 weeks provided that the quality of the initial product is similar to ours. The sensory scores remained almost at baseline levels after 8 weeks' storage. This is probably

271 due to slow development of microbial population. The product reached an APC of 7.0 log

272 CFU/g but after 6 weeks or even longer storage. According to one sensory panel, vacuum- 
273 packaged smoked herring fillets (Magnússon and Traustadóttir, 1982) were still of high 274 quality after 12 weeks’ storage at $10^{\circ} \mathrm{C}$, although a rapid increase in microbes occurred

275 during the first few weeks. The authors speculated that the high numbers of LAB found 276 might play a role in the long shelf-life of the product. With regard to charcoal-broiled river 277 lamprey, this does not appear likely.

The predominant LAB species found here was L. curvatus subsp. curvatus. Only two out of 27 isolates were identified as Leuconostoc spp. Jeppesen and Huss (1993) reported that all isolated LAB from samples of vacuum-packaged minced herring were Leuconostoc spp. Lyhs et al. (1999) found Leuconostoc mesenteroides subsp. mesenteroides, Leuconostoc citreum, Lactobacillus sakei and Lactobacillus curvatus to be the main species associated with spoilage of vacuum-packaged cold-smoked rainbow trout. In our study, ribotyping revealed that only the products from plant A possessed LAB species, three different ribotypes were detected, Lactobacillus curvatus subsp. curvatus most often. Surprisingly, the strains in samples from plant C were identified as Staphylococcus spp. This shows that the MRS medium is not entirely selective for lactic acid bacteria. One ribotype (II) was common to both plants A and C.

Our results are different from findings obtained in studies investigating other fish products. Magnússon and Traustadóttir (1982) stated that LAB increased in vacuum-packaged 293 smoked herring at the expense of other genera, reaching a level of $76 \%$ after 9 weeks' storage. Lyhs et al. (1998) found LAB to predominate in the spoilage population of all samples from vacuum-packaged cold-smoked rainbow trout fillets cured with $\mathrm{NaCl}$. In 296 lampreys, the mean APC values being higher than the mean LAB values indicates that 297 microbial groups other than LAB are also present. This may be due to the different 
processes involved, i.e. smoking versus charring, in the latter of which relatively high temperatures $\left(300^{\circ} \mathrm{C}\right.$ in average) burn the surface of the product, resulting in a dry crispy coating. The values of water activity between 0.93 and 0.98 don't explain the slow microbial development. Altough bacteria recovered in the product such as Lactobacillus, Leuconostoc, Weissella and Staphylococcus have growth potential at that range. Water activity as low as 0.91 allows growth of microorganisms similar to those isolated, although the measurement is complicated by the methodology (Doe, 2002). Because the lampreys stop feeding at the beginning of spawning season and their energy is deposited to fat, they may also have a different nutritional value for microbes, especially for LAB, which usually rely on fermentative carbohydrate metabolism. Since the LAB species detected have been associated with spoilage in other types of fish products, this warrants further study. The different handling of lampreys might also affect the product's initial microbial population; in lamprey processing no raw materials or products other than lampreys are present, and thus, cross-contamination is minimized.

\section{Conclusions}

Our study and the findings of Merivirta et al. (2003) indicate that microbial development in charred river lampreys is slow, and therefore the shelf-life of the product is longer than that of some other fishery products. LAB was not the main bacterial group present. We found the shelf-life of vacuum-packaged-charcoal broiled river lampreys stored at $8^{\circ} \mathrm{C}$ to vary

319 between 5 and 8 weeks depending on the manufacturer. Further experiments are required 320 before conclusions can be drawn of the reasons resulting in low LAB values in lampreys. 
324 The Regional Council of Satakunta partially funded this study. The authors thank the City 325 of Pori (Porilab) for use of their facilities and Ms. Henna Niinivirta for excellent technical 326 assistance.

\section{References}

Amerine, M.A., Pangborn, R.M., Roessler, E.B., 1965. Principles of sensory evaluation of food. Academic Press, New York and London, pp.354-366.

Altschul, S.F., Madden, T.L., Schäffer, A.A., Jinghui Zhang, Zheng Zhang, Miller, W., 333 Lipman, D.J., 1997. Gapped BLAST and PSI-BLAST: a new generation of protein database search programs. Nucleic Acids Research 25, 3389-3402.

Björkroth, J., Korkeala, H., 1996a. Evaluation of Lactobacillus sake contamination in vacuum-packaged sliced cooked meat products by ribotyping. Journal of Food Protection 337 59, 398-401.

338 Björkroth, J., Korkeala, H., 1996b. rRNA gene restriction patterns as a characterization 339 tool for Lactobacillus sake strains producing ropy slime. International Journal of Food 340 Microbiology 30, 293-302.

341 Björkroth, J., Korkeala, H., 1997. Characterization of Lactobacillus fructivorans spoilage

342 in ketchup. Journal of Food Protection 60, 505-509.

343 Björkroth, J., Vandamme, P., Korkeala, H., 1998. Identification and characterization of 344 Leuconostoc carnosum, associated with production and spoilage of vacuum-packaged, 345 sliced, cooked ham. Applied and Environmental Microbiology 64, 3313-3319. 
Björkroth, K.J., Geisen, R., Schillinger, U., Weiss, N., De Vos, P., Holzapfel, W.H.,

347 Korkeala, H.J., Vandamme, P., 2000. Characterization of Leuconostoc gasicomitatum sp.

348 nov. associated with spoiled raw tomato marinated broiler meat strips packaged under

349 modified athmosphere conditions. Applied Environmental Microbiology 66, 3764-3772.

350 Blumberg, H.M., Kielbauch, J.A., Wachsmuth, K., 1991. Molecular epidemiology of

351 Yersinia enterocolitica O:3 infection: use of chromosomal DNA restriction fragment

352 length polymorphism of rRNA gene. Journal of Clinical Microbiology 20, 2368-2374.

353 Civera, T., Parisi, E., Amerio, G.P., Giaccone, V., 1995. Shelf-life of vacuum-packed

354 smoked salmon; microbiological and chemical changes during storage. Archiv für

355 Lebensmittelhygiene 46, 1-24.

356 Doe, P.E., 2002. Fish drying. In: Bremner, H.A. (Ed.), Safety and quality issues in fish 357 processing. Woodhead Publishing Limited, Cambridge, pp.350-358.

358 Finnish Game and Fisheries Research Institute, 1999. Fish processing in Finland 1997, 359 Helsinki, Finland, pp.16-17.

360 Ikonen, E., Kokko, U., Tuunainen, P., Auvinen, H., 1983. Nahkiaisen pyynti Suomessa 361 vuonna 1982. Suomen Kalatalous 50, 90-98.

362 International Organization for Standardization, 1991. International standard, ISO 4833.

363 Microbiology - General guidance for the enumeration of micro-organisms - Colony count

364 technique at $30^{\circ}$ C. $2^{\text {nd }}$ ed. Geneva.

365 Jeppesen, V.T., Huss, H.H., 1993. Characteristic and antagonistic activity of lactic acid 366 bacteria isolated from chilled fish products. International Journal of Food Microbiology 18, $367 \quad 305-320$.

368 Leroi, F., Joffraud, J., Chevalier, F., Cardinal, M., 1998. Study of the microbiological 369 ecology of cold-smoked salmon during storage at $8^{\circ} \mathrm{C}$. International Journal of Food 370 Microbiology 39, 111-121. 
Lyhs, U., Björkroth, J., Hyytiä, E., Korkeala, H., 1998. The spoilage flora of vacuum-

372 packaged, sodium nitrite or potassium nitrite treated, cold-smoked rainbow trout stored at

$3734^{\circ} \mathrm{C}$ or $8^{\circ} \mathrm{C}$. International Journal of Food Microbiology 45, 135-142.

374 Lyhs, U., Björkroth, J., Korkeala, H., 1999. Characterisation of lactic acid bacteria from

375 spoiled, vacuum-packaged, cold-smoked rainbow trout using ribotyping. International

376 Journal of Food Microbiology 52, 77-84.

377 Magnússon, H., Traustadóttir, K., 1982. The microbial flora of vacuum-packed smoked 378 herring fillets. Journal of Food Technology 17, 695-702.

379 Merivirta, L., Korkeala, H., Björkroth, J., 2003. Microbiology of Charcoal-Broiled 380 European River Lampreys (Lampetra fluviatilis) Stored at 3 and $22^{\circ} \mathrm{C}$. Journal of Food 381 Protection 66, 2332-2335.

382 Pitcher, D.G., Saunders, N.A., Owen, R.J., 1989. Rapid extraction of bacteria genomic 383 DNA with guanidium thiocyanate. Letters in Applied Microbiology 8, 151-156.

384 Shimasaki, T., Miake, K., Tsukamasa, Y., Sugiyama, M., Minegishi, Y., Shinano, H., 385 1994. Effect of water activity and storage temperature on the quality and microflora of 386 smoked salmon. Nippon Suisan Gakkaishi 60, 569-576.

387 Truelstrup Hansen, L., 1995. Quality of chilled, vacuum-packed cold-smoked salmon.

388 Thesis, Danish Institute of Fisheries Research, Department of Seafood Research, Technical 389 University, Denmark.

390 Tuunainen, P., Ikonen, E., Auvinen, H., 1980. Lamprey and lamprey fisheries in Finland. 391 Canadian Journal of Fisheries and Aquatic Sciences 37, 1953-1959. 
398 Fig. 1. Ribopatterns generated by HindIII restriction enzyme and the numerical analysis of

399 the patterns presented as a dendrogram. Left side of the banding patterns, high molecular 400 masses (<23 kbp); right side, low molecular masses (>500 bp).

401

402

403

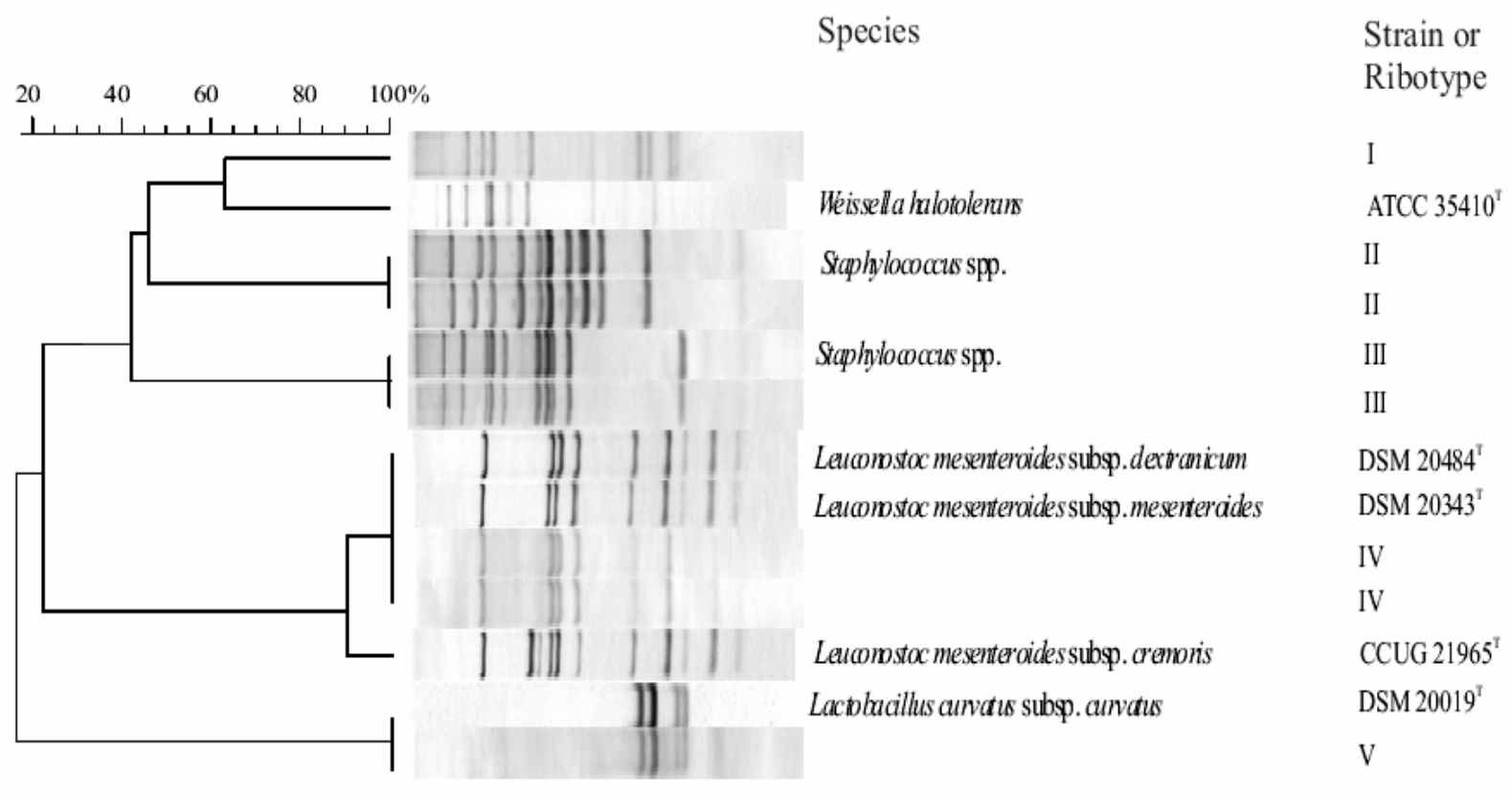

Fig. 1. Merivirta et al. 
Table 1

Mean and range of aerobic bacterial counts $\left(\log _{10} \mathrm{CFU} / \mathrm{g}\right)$ and mean taste scores of vacuum-packaged charcoal-broiled river lampreys stored at $8^{\circ} \mathrm{C}$.

(weeks)

$414{ }^{\mathrm{b}} \mathrm{ND}=$ not detected; assigned $2.70 \log \mathrm{CFU} / \mathrm{g}$ for calculation of mean.

$415{ }^{\mathrm{c}}$ Means within a row with same letter are not significantly different at $\mathrm{p}>0.05$.

416

417

418

419

420

421

422

423

424 
Table 2

Mean and range of lactic acid bacteria counts $\left(\log _{10} \mathrm{CFU} / \mathrm{g}\right)$ after anaerobic incubation and mean taste scores of vacuum-packaged charcoal-broiled river lampreys stored at $8^{\circ} \mathrm{C}$.

\begin{tabular}{|c|c|c|c|c|c|c|c|c|c|c|}
\hline \multirow{3}{*}{$\begin{array}{l}\text { Storage time } \\
\text { (weeks) }\end{array}$} & \multirow[t]{3}{*}{$\mathrm{n}$} & \multicolumn{9}{|c|}{ Plant } \\
\hline & & \multicolumn{3}{|c|}{$A$} & \multicolumn{3}{|c|}{ B } & \multicolumn{3}{|c|}{$\mathrm{C}$} \\
\hline & & Mean & Range & Taste $^{a}$ & Mean & Range & Taste & Mean & Range & Taste \\
\hline 1 & 5 & $\mathrm{ND}^{\mathrm{b}}$ & & 7.6 & ND & & 7.7 & ND & & 7.5 \\
\hline 2 & 5 & ND & & 7.5 & ND & & 6.4 & ND & & 7.5 \\
\hline 3 & 5 & 3.40 & ND-6.20 & 7.6 & ND & & 7.3 & ND & & 7.1 \\
\hline 4 & 5 & 3.46 & ND-6.49 & 7.6 & ND & & 7.6 & ND & & 7.5 \\
\hline 5 & 5 & ND & & 7.2 & ND & & 7.1 & 3.10 & ND-4.72 & 6.7 \\
\hline 6 & 5 & 4.34 & ND-7.08 & 7.6 & ND & & 6.7 & 3.07 & ND-4.56 & 6.9 \\
\hline 7 & 5 & 4.07 & ND-7.97 & 7.8 & ND & & 7.3 & 3.26 & ND-5.48 & 7.1 \\
\hline 8 & 5 & 4.86 & ND-8.04 & 7.7 & ND & & 8.0 & $\mathrm{ND}$ & & 6.6 \\
\hline
\end{tabular}

428 a Score range $0-10$.

$429{ }^{\mathrm{b}} \mathrm{ND}=$ not detected; assigned $2.70 \log \mathrm{CFU} / \mathrm{g}$ for calculation of mean. 